\title{
Legal Politics In The Establishment Of State-Owned Enterprise Holding \& Its Impact
}

\author{
Indah Riyanti ${ }^{1}$ \\ \{Indah.brown@gmail.com\} \\ ${ }^{1}$ Postgraduate Program of Law, Jayabaya University, Indonesia
}

\begin{abstract}
The research aims to find a design model of legal aspects in the formation of a holding SOE after the issuance of Government Regulation Number 72 of 2016. This research uses a descriptive or doctrinal normative approach using secondary data types. The results show that there are still overlapping regulations in various laws and regulations that cause contradictions and legal uncertainty in the management, supervision and guidance of SOEs. The government should together with the Parliament to revise Law No. 17 of 2003 concerning State Finance and Law No. 19 of 2003 concerning SOEs to be perfected by including elements of the holding of SOEs
\end{abstract}

Keywords; Political Law, BUMN Holding

\section{Introduction}

"BUMN for Indonesia", this is the latest tagline that was tried to be built by the Ministry of SOE since February 2020 ago.[1] The hope of this tagline change is certainly not merely a sentence change but is expected to have a broad and meaningful meaning. The tagline "BUMN for Indonesia" gives more understanding that BUMN is owned by all Indonesian citizens and has the right to enjoy the services of all existing SOEs. BUMN is a real manifestation of the fourth paragraph of the Preamble to the 1945 Constitution.[2]

In line 4 of the Constitution 1945 : "Then to form a government of Indonesia that protects the whole Indonesian nation and the whole blood of Indonesia and to promote the common good, to sanctify the nation, and to enact world order based on independence, eternal peace and social justice, then Indonesia's independence was enshrined in the Constitution of Indonesia, established in a constitution of the Republic of Indonesia, which is governed by the people on the basis of; the Divine Divinity,; the just and civilized humanity; the Indonesian Society,; led by the wisdom of counseling / representation, and by establishing a social justice for all Indonesian people.[2]

Emphassized in Constitution 1945 Article 33;

(1) The economy is organized as a joint venture based on a family basis.

(2) The branches of production that are important to the country and which dominate the lives of the people are dominated by the state.

(3) The earth and the water and the natural resources contained therein are controlled by the nation and used for the greater prosperity of the people.

(4) The national economy is organized on the basis of economic democracy with the principles of togetherness, efficiency of justice, sustainability, environmental awareness, independence, and by maintaining a balance of progress and unity of national economy.

(5) Further provisions on the implementation of this article shall be governed by law.[2] 
Based on the two elements of the above State policy to realize it in the national life, the government finally established a State Owned Enterprises (PERSERO) as defined in Government Regulation Number 12 of 1998 and Public Enterprises (PERUM) as intended in Government Regulations. Number 13 of 1998. [3] However, lately SOEs have always been hit by various issues up to the National level.[4] One of the most widespread issues is the presence of steam by the Government conducting a "Holding Company" of StateOwned Enterprises (SOEs) spread throughout Indonesia based on the qualifications of their core businesses. [5]

The urgency of establishing a Holding Company has been started since 2016[6], namely since the issuance of Government Regulation No. 72 of 2016 concerning Amendments to Government Regulation No. 44 of 2005 concerning Procedures for Participation and Administration of State Capital in State-Owned Enterprises and Limited Liability Companies.[7]

Since then many opinions have alternated between the Pros and Cons of the Holding Company plan.[8] The process and procedure for the formation of a Holding Company is strongly influenced by the political atmosphere of government law in the effort to empower and renew the structure of the development and management of SOEs in order to accelerate the achievement of target goals and fulfillment of the benefits to be used to meet the welfare of the Indonesian people.[9]

This paper will raise issues relating to legal politics in the formation of BUMN holding companies in the mining sector as well as the impacts caused by holding companies.

\section{Method}

This study uses a normative juridical research method (Legal research) that is descriptive, describing the research qualitatively. The secondary data collection used in this study focused on: (a) the primary legal entity, in the form of legislation related to the research theme; and (b) secondary legal material, in the form of reference books and journals related to the research theme and further elaborating primary legal materials into theoretical contexts.

\section{Research and Discussion}

\subsection{State-Owned Enterprises (BUMN)}

Based on the Law of the Republic of Indonesia Number 19 of 2003 concerning StateOwned Enterprises (SOEs) in particular article 2. SOEs have the purpose and objectives in the form of $[10]$ :

1) Contribute to the development of the national economy in general and state revenue in particular;

2) Pursuing profits; [11]

3) Carrying out public benefits in the form of high quality and adequate provision and / or services for fulfilling the lives of many people;

4) Pioneering business activities that cannot yet be carried out by the private sector and cooperatives;

5) Also actively providing guidance and assistance to economically disadvantaged entrepreneurs, cooperatives, and the community.[12]

State-Owned Enterprises which are one of the agents of economic activity in the national economy based on economic democracy have an important role in administering the 
national economy in order to realize the welfare of society as mandated by the 1945 Constitution. These goals are then translated into SOE Functions and Roles, namely:[13]

1) As a provider of economic goods and services that are not provided by the private sector; [14]

2) Is a government tool in managing economic policies; [15]

3) As manager of the branches of natural resource production for the community at large;

4) As a service provider in community needs; [16]

5) As a producer of goods and services for the fulfillment of many people;

6) As a pioneer in the business sectors that have not been interested in by the private sector; [17]

7) Job opening;

8) State foreign exchange earners;

9) Assistance in the development of cooperative small businesses,

10) Drivers of community activities in various business fields.

BUMN is a State-Owned Enterprise in the form of a Company Company (PERSERO) as referred to in Government Regulation Number 12 of 1998 and Public Corporation (PERUM) as referred to in Government Regulation Number 13 of 1998.[18] A State-Owned Enterprise (BUMN) is one of the perpetrators of activities an important economy in the national economy, which together with other economic actors, namely the private sector (large-small, domestic-foreign) and cooperatives, is an embodiment of the form of building an economic democracy that we will continue to develop gradually and sustainably. [19]

BUMN is a Government-owned company in which the ownership of shares is fully owned by the Government with a mechanism of capital participation where the capital participation is based on the separated state assets.[20] BUMN with its various business units is divided into two different legal entities, yani;[21]

1) BUMN Legal Entity. This SOE is a BUMN that has limited capital, so that to meet the needs of the total capital is given the opportunity for other parties (other than the government) to invest capital provided that [capital participation from third parties must not exceed the amount of capital owned by the Government by at least $51 \%$ ( fifty one percent) so that the main goal of pursuing profits can be achieved;[22]

2) Publicly traded legal entities (PERUM) are SOEs whose entire capital is owned by the state and is not divided into shares. The main objective of PERUM's legal entity BUMN is for public benefit in the form of providing high quality goods and / or services and at the same time pursuing profits based on the principles of company management.[23]

\subsection{Legality and Concept of BUMN Holding Company.}

The concept of holding for downsizing the number of State-Owned Enterprises (SOEs) in Indonesia has been poured since 1998. The idea of holding SOEs by grouping SOEs into each industry was raised in the era of the first SOE Minister, the Tanri Abeng era.[24] The concept of holding BUMNs is considered by Tanri to create a strong BUMN. The state-owned company is also considered to be increasingly focused on developing its business from upstream to downstream. The holdin concept began in the days of the Minister of SOEs held by Tanri Abeng. The concept of the BUMN Holding Company proposes that several SOEs be combined, namely:[25]

1) BUMN engaged in the Energy and mining business, united into one BUMN only; [8] 
2) BUMN engaged in infrastructure business such as ports, airports, transportation and telecommunications. [26] Then the financial sector holding, the contents are all banks and nonbanks combined combined into one BUMN; [27]

3) BUMN engaged in cement and construction.[28]

4) BUMN engaged in fertilizer and plantations. [29]

The Ministry of State-Owned Enterprises (BUMN) is currently trying to form a holding BUMN mine. The establishment of a mining SOE holding is done by appointing PT Indonesia Asahan Aluminum (Persero) (Inalum) as the holding holding company.[30] Inalum will be the parent of three mining SOEs, including PT Timah (Persero) Tbk, PT Aneka Tambang (Persero) Tbk (Antam) and PT Bukit Asam (Persero) Tbk (PTBA). State ownership status in the three SOEs has been lost through the Extraordinary General Meeting of Shareholders (EGMS) November 29, 2017. Elimination of state ownership is carried out by transferring government-owned shares in the three mining SOEs to PT Indonesia Asahan Aluminum (Persero) (Inalum) as holding parent BUMN BUMN.[25] The government currently holds majority shares in the three mining SOEs that have also gone public, namely Antam 65\%, PTBA $65.02 \%$, and Tin $65 \%$. The majority shares owned by the government in the three SOEs were transferred to Inalum, which is $100 \%$ still owned by the state. The Deputy for Mining, Strategic Industry and Media at the Ministry of SOEs, emphasized that the transfer of the shares of the three mining SOEs to Inalum does not necessarily mean that government control is lost. The government still has the authority to supervise the three BUMNs even though a holding has been formed under Inalum with the existence of a dual A series stock. "The answer is that there are stateowned companies because there are dual-colored shares," said Harry in Jakarta, as written in Kompas newspaper Friday (11/24/2017).

The steps that have been taken by the Government in forming a holding company of a BUMN in Indonesia by appointing a certain BUMN BUMN as a holding company and merging a similar BUMN BUMN into a subsidiary through a share transfer mechanism (inbreng) is something new in Government companies (BUMN).[20] So far, there are no specific legal rules governing the existence of a holding company in Indonesia, but since the Government Regulation No. 72 of 2016 concerning Amendments to Government Regulation no. 44 of 2005 concerning Procedures for Participation and Administration of State Capital in State-Owned Enterprises and Limited Liability Companies.[7]

The existence of a BUMN holding company and an inbreng (share transfer) mechanism must be able to be an encouragement and a new moral injection for all levels of BUMN stake holders in order to advance a company that is developed and competitive so that it becomes a highly competitive company at regional and international levels. Apart from that, after the establishment of the BUMN holding company, the performance of all BUMN employees remains to be watched and guarded to the maximum in order to avoid the mis BUMN vision for Indonesia becoming a onesided and a group of people. Thus the benefits obtained by SOEs can truly be felt by all levels of citizens throughout Indonesia.

\subsection{Impact of BUMN Holding Company}

Zainal C. Airlangga, an observer of BUMN stated (Ekonimi Daily Balance 07/26/2019) "The government is now working on the concept of holding State-Owned Enterprises (SOEs) in various sectors. Later SOEs will be combined in one holding company in accordance with their respective sectors. This plan was reaffirmed by President Joko Widodo (Jokowi) while speaking at the Final Debate of the 2019 Presidential Election at the Sultan Hotel, Central Jakarta, last Saturday (13/4). 
"There will be holding parties, on top of which there will be superholding. The BUMN holding is to strengthen the ability of many state-owned companies in developing business. "If we do all this, and the private sector will follow behind it, this is Indonesia Incoporation," Jokowi explained.

Zainal C Airlangga highlighted that the government's plan has been stated in Government Regulation Number 72 of 2016 concerning Procedures for the Participation and Administration of State Capital in SOEs and Limited Companies. So that the potential to cause negative impacts, among others;[7]

1) Covert Privatization

Although the government claims that holding has a variety of benefits, there are also threats behind the formation of this sectoral BUMN holding. Businessmen, for example, highlight the possibility of monopolistic practices and cartelization. The formation of this holding also has the potential to violate Law Number 5 of 1999 concerning Business Competition which does not tolerate SOEs. The Business Competition Supervisory Commission (KPPU) has warned about this danger. Article 12 based on the Law: "Business actors are prohibited from making agreements with other business actors to cooperate with forming a joint company or a larger company."[31]

2) SOEs that turn out to be much bigger will potentially become unhealthy. In this process, cross-funding cannot run optimally if many of the subsidiaries under it are unhealthy. In this case a healthy company is forced to bear losses. [8]

3) There is a legal loophole that has the potential to become a dispute in the future, namely the decision to transfer ownership from the government to the private sector and even to foreigners so that the formation of BUMN holding and superholding is suspected of being a hidden privatization.[6] Moreover PP No. 27 of 2016 gives flexibility to the government to form a holding without the approval of the DPR. This can also revoke the identity of SOEs from Article 33 paragraph (2) of the Constitution "The important branches of production are for the state and which control the livelihoods of the people are controlled by the state".

4) Potential problems in the legal status of BUMN. In Law Number 19 Year 2003 concerning SOEs, it is stated that what is categorized as BUMN is limited to the holding company.[21] By becoming a subsidiary, (under the PT Law) there is no longer a government oversight function. Related to this, the government has indeed proposed revision of the BUMN Law No. 19/2003. Unfortunately, the contents of the bill (article 4 paragraph 1) contains the DPR's authority over SOEs to be superior: they have the right to determine the board of directors, commissioners, and corporate business strategy.

Meanwhile, University of Indonesia economist Faisal Basri considers that the SOE Ministry's plan related to holding is only as a smoothing tool to increase its debt capacity. "I also had a chat with one of the deputies of the Ministry of SOEs, he said that the capacity of his debt to increase," said Faisal in the event of Exploring Profit and Loss Holding BUMN, Jakarta, some time ago. alone, but state control and people's constitutional rights to SOEs (in accordance with article 33) must not be negated because historically, SOEs are part of the struggle of the Indonesian people.This is the 
philosophical and constitutional basis why the people give a mandate to the government to manage the country's wealth and interests the lives of many people through state enterprises.[32]

\section{Conclusions}

a. That the legal substance issued for the establishment of BUMN holding companies is often in contradiction with and contradictory with Law No. 17 of 2003 concerning State Finances, Law No. 19 of 2003 concerning SOEs and Law Number 40 of 2007 concerning Limited company.

b. The thick legal policy behind BUMU's Holding Company still concerns issues - problems that could become a time bomb in the future, namely:

1) There is potential for Covert Privatization.

2) The potential of BUMN will suffer from the large capital expenditure in running the business wheels;

3) Potential legal loopholes in the occurrence of disputes regarding the transfer and transfer of BUMN share ownership;

4) Potential violations of the legal basis where Government Regulation Number 72 of 2016 concerning Procedures for Participation and Administration of State Capital in SOEs and Limited Liability Companies is contrary to Law Number 19 of 2003 concerning SOEs;

\section{References}

[1] Kompas.com, "https://money.kompas.com/read/2020/04/13/154348326/erick-thohir-ubahslogan-bumn." 2020.

[2] Indonesia, "Undang-Undang Dasar Tahun 1945," vol. 4, no. 1, pp. 1-12, 1945.

[3] M. F. Nauvaldy, "Keabsahan Pembentukan Holding Badan Usaha Milik Negara Minyak Dan Gas (Bumn Migas).," Dr. Diss. Univ. Airlangga, pp. 1-24, 2020.

[4] Sentosa Sembiring, "Hukum Perusahaan Dalam Peraturan Perundang-Undangan," Nuansa Aulia, 2006.

[5] P. H. Kristianto and T. A. Candini, "Kualifikasi Badan Usaha Pada Pengembangan Unit Usaha Pada Grup Usaha BUMN,” J. Paradig. Huk. Pembang. 4.02, pp. 80-97., 2019.

[6] K. Mangkusubroto, "Privatisasi Sebagai Kecenderungan Lingkungan Usaha BUMN," J. Technol. Manag., vol. 10, no. 2, pp. 114-294, 2011.

[7] S. H. Rahayu, "Sinkronisasi Peraturan Pemerintah Nomor 72 Tahun 2016 Tentang Cara Penyertaan Modal Negara Dengan Undang-Undang Nomor 17 Tahun 2003 Tentang Keuangan Negara Mengenai Penyertaan Modal Negara Pada BUMN Tanpa Melalui APBN," Dr. Diss. Univ. Brawijaya, no. 2, 2017.

[8] S. A. Airlangga, "Dilema Holdingisasi BUMN Migas: Diantara Efektifitas Kinerja dan Hilangnya Status Kelembagaan," Fac. Soc. Polit. Gajah Mada Univ., no. April, pp. 0-18, 2019.

[9] F. Ali, "Antara Pasar Dan Politik: BUMN Di Bawah Dahlan Iskan," Kepustakaan Pop. Gramedia, 2013.

[10] Indonesia, "Undang-Undang NO. 19 Tahun 2003 Tentang Badan Usaha Milik Negara," no. 1, pp. 2-3, 2003.

[11] A. Alimudin, A. Z. Falani, S. W. Mudjanarko, and A. D. Limantara, "Analisis Pengaruh Penerapan Perspektif Balanced Scorecard Terhadap Peningkatan Kinerja UMKM," E-ISSN 
2581-2157, Vol. 4, No. 1, April 2019, vol. 4, no. 1, pp. 1-17, 2019.

[12] Surjono, P. Ariwibowo, and M. Nizma, "Penerapan Standarisasi Laporan Keuangan Umkm Bagi Pengusaha Kecil Menengah Untuk Meningkatkan Kinerja Usaha," $p$-ISSN 2614-574X, eISSN 2615-4749, Vol. 01 No. 03, Sept. 2018, vol. 01, no. 03, pp. 295-303, 2018.

[13] I. Avianti, "Privatisasi BUMN dan Penegakan Good Corporate Governance dan Kinerja BUMN," Kinerja, Vol. 10, No.1, Th. 2006, vol. 9, no. 2, pp. 57-65, 2017.

[14] Y. Sumiyati, "Peranan BUMN dalam Pelaksanaan Tanggung Jawab Sosial Perusahaan untuk Meningkatkan Kesejahteraan Rakyat," J. Huk. Ius Quia Iustum 20.3, vol. 20, no. 3, pp. 460-481, 2013.

[15] M. Asnawi, "Implikasi Pengelolaan Bumn Persero Dalam Kerangka Welfare State Berdasarkan Mekanisme Perseroan Terbatas," J. Huk. Samudra Keadilan, vol. 11, no. 1, pp. 126-144, 2016.

[16] T. Haryanto, "Eksistensi Bumn Tidak Mengarah Pada Etatisme," J. Wacana Huk., vol. 7, no. 1, pp. 43-61, 2008.

[17] I. Pratiwi, "Peranan Bumn Dalam Memberikan Pinjaman Modal Kepada Pengusaha Kecil," J. Pionir 2.5 LPPM, vol. 53, no. 9, pp. 1689-1699, 2018.

[18] Indonesia, "Peraturan Pemerintah NO. 13 Tahun 1998 Tentang Perusahaan Umum (PERUM)," 1998.

[19] A. Shandy Utama, "Independensi Pengawasan Terhadap Bank Badan Usaha Milik Negara (Bumn) Dalam Sistem Hukum Nasional Di Indonesia," Soumatera Law Rev. 1.1, vol. 1, no. 1, pp. 1-21, 2018.

[20] M. Suhayati, "Negara Melalui Mekanisme Penawaran Umum (Initial Public Offering)," Negara Huk. Membangun Huk. untuk Keadilan dan Kesejaht. 2.1, pp. 51-74, 2016.

[21] Natun Smaud Julio Thimotius Kapitan, "Status Kepemilikan Anak Perusahaan BUMN," Dr. Diss. Univ. 17 Agustus 1945, pp. 129-133, 2018.

[22] F. Margaretha and K. Ginting, "Faktor-Faktor Yang Mempengaruhi Struktur Modal Pada Perusahaan Bumn Di Indonesia," J. Ekon. Univ. Esa Unggul, 7.01, vol. 7, no. 01, 2016.

[23] R. Burton, "Kajian Hukum Tentang Kepemilikan Modal Terhadap Badan Usaha Milik Negara Menjadi Badan Usaha Milik Swasta," Lex Crim. 5.3, vol. 5, no. 3, pp. 57-65, 2016.

[24] R. A. Sumarna and A. Solikin, SE, MA, PhD, "Pengaruh Restrukturisasi Melalui Pembentukan Holding Bumn Terhadap Kinerja Keuangan Bumn," Substansi Sumber Artik. Akunt. Audit. dan Keuang. Vokasi 2.2, vol. 2, no. 2, p. 240, 2018.

[25] Triarda, Reza, and R. Zulfikar, "Revitalisasi Indonesia Incorporated: Super Holding Dan Internasionalisasi Bumn Indonesia," Transform. Glob. 6.1, pp. 1-34, 2020.

[26] A. Dinarjito, "Menilai Kesehatan BUMN Konstruksi yang Terdaftar di Bursa Efek Indonesia sebagai Akibat Meningkatnya Proyek InfrastrukturPemerintah," Substansi 2.1, vol. 2, no. 1, pp. 1-18, 2018.

[27] A. Prasetiyo, "Restrukturisasi Badan Usaha Milik Negara Perbankan Melalui Pembentukan Holding Company Di Indonesia," Lex Renaiss. 4.2, pp. 285-302, 2019.

[28] W. ASTUTI, "Kebijakan Strategic Holding Perusahaan Semen Nasional Ditinjau Dari Perspektif Sumber Daya Manusia (Kasus Pada PT Semen Tonasa)," Dr. Diss. Univ. Negeri Jakarta, 2020.

[29] Harun, Amran, and A. Asriyati, "Analisis Kinerja Keuangan PT Perkebunan Nusantara Sebelum Dan Sesudah Holding," Pros. Semdi-Unaya (Seminar Nas. Multi Disiplin Ilmu UNAYA). Vol. 3. No. 1., 2019.

[30] Negara and A. Permata, "Analisis Yuridis Terhadap Kebijakan Privatisasi Bumn Pada Sektor Pertambangan Di Indonesia," J. Cakrawala Huk. 13.2, 2018.

[31] A. S. Judhanto, "Pembentukan Holding Company BUMN dalam Perspektif Hukum Persaingan Usaha," J. Spirit pro Patria, vol. IV, no. 2, pp. 154-170, 2018. 
[32] Y. P. Ginting, "Holding Bumn Memerlukan Adanya Standar Prosedur Operasi Dalam Mencapai Aspek Tata Kelola Perusahaan Yang Baik," Maj. Huk. Nas. 50.1, vol. 50, no. 1, pp. 1$18,2020$. 